\title{
BESIMANKŠTINANČIŲ ASMENŲ DEMOGRAFINIŲ VEIKSNIŲ IR MANKŠTINIMOSI MOTYVŲ SĄSAJOS SU VALGYMO SUTRIKIMŲ RIZIKA
}

\author{
Rasa Jankauskienė, Rasa Mickūnienė \\ Lietuvos kūno kultūros akademija, Kaunas, Lietuva
}

\begin{abstract}
Rasa Jankauskienė. Docentė socialinių mokslų daktarè. Lietuvos kūno kultūros akademijos Sveikatos ir fizinio aktyvumo katedros vedėja.
\end{abstract} Mokslinių tyrimų kryptis — ivvairaus amžiaus žmonių kūno masės kontrolè ir su fiziniu aktyvumu susijęs elgesys.

\section{SANTRAUKA}

Atlikta daugybe tyrimu, atskleidžiančiu, kad valgymo sutrikimai labiau paplite tarp profesionaliai sportuojančiu (ypač kultivuojančiı estetines sporto šakas) negu bendroje populiacijoje. Naujausi tyrimai atskleidžia, kad asmenys, besimankštinantys sveikatingumo centruose, dažniau kenčia nuo valgymo sutrikimu nei kitur sportuojantys. Nemažai tyrimu atlikta tiriant vaiku, jaunimo ir studentu mankštinimosi motyvacijos, valgymo sutrikimu rizikos ryšius, tačiau mažiau žinoma, kaip demografiniai bei mankštinimosi veiksniai gali būti susiję su besimankštinančiu suaugusiu asmenu, ypač vyru, valgymo sutrikimu rizika.

Šio tyrimo tikslas - nustatyti, kaip demografiniai (lytis, amžius, išsilavinimas) ir mankštinimosi (motyvacija, stažas) veiksniai susije su besimankštinančiu asmenu valgymo sutrikimu rizika.

Tyrimo imtis ir organizavimas. Tyrimas buvo atliekamas 2008 metu pavasari keliuose Kauno sveikatingumo centruose, taikant apklausos raštu metodq. Iš viso buvo analizuoti 239 tiriamuju duomenys, iš ju - 81 vyras (amžiaus vidurkis (SD) 30,8 $\pm 8,9$ m.).

Tyrimo instrumentas. Anketq sudare demografiniu klausimu blokas. Valgymo sutrikimu rizika nustatyta taikant Požiürio ì valgyma testa (Eating Attitude Test-26, Garner, 1982). Mankštinimosi motyvacija buvo nustatoma remiantis apsisprendimo teorijos pagrindu sukurtu klausimynu (angl. Motives for Physical Activity Measure-Revised; MPAM-R) (Frederick, Ryan, 1993).

Rezultatai. Bendras šios imties tiriamuju valgymo sutrikimu rizikos balu vidurkis buvo 7,67 \pm 8 balo. $!$ valgymo sutrikimu rizikos grupe (surinko 20 ir daugiau balu) pakliuvo 21 (9,1\%) tiriamasis, iš ju - 7 (8,64\%) vyrai ir 14 (8,86\%) moteru. Logistinè regresine analize atskleidè, kad mankštinimasis dèl išvaizdos ( $p<0,05)$, ilgesnis mankštinimosi stažas $(p>0,05)$ ir mankštinimosi dažnis buvo susiję su didesne valgymo sutrikimu rizika $(p>0,05)$.

Išvados. Valgymo sutrikimu rizika yra paplitęs reiškinys tarp besimankštinančiu asmenu. Moteriška lytis, amžius ir aukštesnis išsilavinimas nèra reikšmingai susije su sveikatingumo centruose besimankštinančiu asmenu valgymo sutrikimu rizika. Mankštinimasis dèl išvaizdos gerinimo motyvo yra svarbiausias valgymo sutrikimus prognozuojantis veiksnys $(p<0,05)$. Tyrimas pagrindžia prevenciniu programu bei vidinès motyvacijos stiprinimo bütinybę sveikatingumo centruose ir atskleidžia šiu programu reikalingumq vyrams.

Raktažodžiai: valgymo sutrikimai, fizinis aktyvumas, mankštinimosi motyvacija.

\section{IVADAS}

$\mathrm{V}$ algymo sutrikimai yra reta liga, tačiau vakarų šalys i ją atkreipia dèmesį dẻ jauno pacientų amžiaus ir santykiškai didelio mirtingumo (Herzog et al., 2000). Anoreksija ir bulimija sergančio asmens gydymo išlaidos Vokietijoje siekia atitinkamai 5300 ir 1300 Eu per metus (Krauth et al., 2002). Maždaug 0,5-3\% paaugliu ir jaunimo yra diagnozuojami valgymo sutrikimai, o valgymo sutrikimų rizika būdinga maždaug $8,4-15 \%$ studenčių ir 4\% studentu (Austin et al., 2008). Lietuvoje atliktų epidemiologinių tyrimų autorèms aptikti nepavyko.

Tyrimai rodo, kad besimankštinančios moterys dažnai nepagrisstai siekia mažinti kūno svorị, jų motyvacijoje vyrauja išvaizdos tobulinimo tikslai. Moterys dažniau patiria nerimą dèl savo išvaizdos, 
tačiau ỉsipareigojantis požiūris į mankštinimąsi yra vienodas abiems lytims (Chu et al., 2008). Anksčiau atliktais tyrimais nustatyta, kad išorinè mankštinimosi motyvacija (mankštinimasis dèl išvaizdos) yra susijusi su didesne moteru valgymo sutrikimu rizika, tačiau mažiau žinoma, kaip ši motyvacija susijusi su vyru valgymo sutrikimų rizika.

Vyrai vis labiau patiria spaudimą atitikti socialinius išvaizdos lūkesčius (siekti raumeningos, tačiau lieknos figūros), todèl ir vyrams išvaizdos kontrolè darosi vis aktualesnè (Walker et al., 2009). Sveikatingumo centrų treniruoklių salèse besimankštinantys vyrai laikytini specifine didesnès kūno vaizdo sutrikimų rizikos grupe. $\mathrm{Pa}-$ vyzdžiui, lyginant futbolininkus ir treniruokliu salėse besimankštinančius nustatyta, kad pastaruju raumenu dismorfijos (angl. muscle dysmorphia), t. y. nepagristo siekimo didinti raumenu apimti, testo rezultatai buvo kur kas aukštesni (Baghurst, Lirgg, 2009).

Stebejimo studijos atskleidžia, kad moterys yra labiau nepatenkintos savo išvaizda nei vyrai (Keel et al., 2007). Nutukimas siejamas su žemesniu išsilavinimu (Klumbiene et al., 2004), žemesnio išsilavinimo moterys yra inertiškesnès per žiniasklaidą perduodamos informacijos apie sveiką gyvenseną prièmimui (Iversen, Kraft, 2006). Išsilavinimo ir valgymo sutrikimų rizikos sąsajos yra nevienalytės: nèra aiškiu irodymų, kad valgymo sutrikimų rizika būdingesnè aukštesnio išsilavinimo ar socialinio-ekonominio statuso žmonėms, atvirkščiai, daroma prielaida, kad bulimija gali būti dažnesnè tarp žemesnio išsilavinimo asmenu (Gard, Freeman, 1998).

Pastaruoju metu atkreipiamas dėmesys į vyresnio amžiaus moteris. Yra duomenų, kad valgymo sutrikimais gali sirgti panašus procentas $60-70$ metų amžiaus moterų, kurios dèl senèjimo išgyvena socialinio statuso, dažnai siejamo su išvaizda, mažejjimą (Peat et al., 2008). Tyrimai atskleidžia, kad moterų požiūris i savo kūną nesikeičia didèjant amžiui. Analizuojant 17-60 metu amžiaus moteris nustatyta, kad vyresnio amžiaus moterys taip pat nepatenkintos savo išvaizda, kaip ir jaunesnès (Šivert, Simanovič, 2008). Moteru dažnas svorio metimas, nepasitenkinimas savo išvaizda, didesnè suvokiama išvaizdos reikšmè gyvenimo kokybei susijusi su mažesne tikimybe realiai sumažinti kūno masę (Teixeira et al., 2006).

Norèdami paaiškinti valgymo sutrikimų riziką tarp besimankštinančiu asmenų, mokslininkai atkreipia dèmesi i mankštinimosi motyvų svarbą. Apsisprendimo motyvacijos teorija teigia, kad asmenys ilgiau tęsia tam tikrą veiklą, jei yra patenkinami pagrindiniai autonomijos, kompetencijos ir prisirišimo poreikiai. Šie poreikiai paprastai yra tenkinami, jei tam tikros veiklos motyvacijoje dominuoja vidiniai siekiai (Ryan et al., 1997). Atvirkščiai, jei motyvacijoje vyrauja išoriniai motyvai, tikimybė tęsti veiklą ilgą laiką yra mažesnè, be to, tyrimai atskleidžia, kad išorinè veiklos motyvacija sietina su prastesne psichosocialine sveikata. Anot R. M. Ryan ir kt. (1997), asmenys gali mankštintis dèl malonumo, socialiniu (bendravimo) motyvų, dèl sveikatos arba fizinio pajègumo, dèl fizinès kompetencijos ir išvaizdos. Mankštinimosi motyvai dèl malonumo, sveikatos, fizinès kompetencijos motyvu priskiriami vidinès motyvacijos rūšiai, o mankštinimasis dèl išvaizdos ar fizinio pajègumo gerinimo rodo išorinę asmens motyvaciją, nors patys motyvai iš esmès neatskleidžia motyvacijos reguliaciniu mechanizmu (autonomiškos ar kontroliuojamos reguliacijos lygmens).

Lyginant sergančias valgymo sutrikimais ir sveikas moteris nustatyta, kad sergančios moterys dažniau jaučia kaltę praleidusios pratybas ir dažniau mankštinasi dèl fizinès išvaizdos gerinimo motyvu (Mond, Calogero, 2009). Kalte praleidus pratybas ir mankštinimasis dèl išvaizdos gerinimo motyvų laikomi pagrindiniais perdozuoto mankštinimosi, lydimo valgymo sutrikimų, požymiais (Mond et al., 2006).

Mankštinimosi veiksnių sąsajos su valgymo sutrikimų rizika yra nevienalytès. Tyrimai atskleidžia: mankštinimasis treniruoklių salejje teigiamai keičia problemini moteru kūno ìvaizdi (Depick, Williams, 2004); valgymo sutrikimų simptomai yra susiję su issipareigojančiu požiūriu mankštintis (Seigel, Hetta, 2001); fizinio aktyvumo kiekis nèra susijęs su valgymo sutrikimu rizika ir nepasitenkinimu savo išvaizda (D. S. de Araujo, C. G. de Araujo, 2003). Taigi fizini aktyvumą skatinančios programos turi pašalini poveiki, t. y. be fizinio aktyvumo dideja moteru noras suliesèti (Zabinski et al., 2001). Tiriant studentus nustatyta, kad valgymo sutrikimu rizika tarp sportuojančiu nėra dažnesnè, tačiau ji dažniau pasitaiko tarp kultivuojančių aerobiką ir sportuojančių treniruoklių salèse (Kjelsas, Augestad, 2004).

Daugiau valgymo sutrikimu ir maitinimosi ipročių tyrimų atlikta su profesionaliai sportuojančiais asmenimis, ypač moterimis. Šie tyrimai atskleidžia, kad studentès, kurios kultivuoja su estetika susijusias sporto šakas, yra didesnès valgymo sutrikimų rizikos grupejje nei kultivuojančios kitas 
sporto šakas (Reinking, Alexander, 2005). Subjektyviai nurodomas energijos deficitas siejamas su moteru menstruacinio ciklo sutrikimais (Abraham et al., 2006). Didžiojo sporto atstovèms būdingas valgymo sutrikimu, sutrikusio menstruacinio ciklo ir osteoporozès požymių kombinacijos fenomenas, ivvardijamas sportuojančių moterų triada (angl. female athlete triad).

Deja, daugelio tyrimų trūkumą rodo tai, kad valgymo sutrikimų rizika yra tyrinèta tik tarp moteru. Daugelis kūno vaizdo ir valgymo sutrikimu tyrimų buvo atlikti tarp paauglių moterų ir jaunimo populiacinių grupių, todèl mažiau žinoma, kaip amžiaus ir lyties veiksniai susiję su besimankštinančių asmenų valgymo sutrikimų rizika.

Todèl šiuo tyrimu kèlème tikslą — nustatyti, kaip demografiniai (lytis, amžius, išsilavinimas) ir mankštinimosi veiksniai (motyvai, stažas) susiję su besimankštinančių asmenų valgymo sutrikimu rizika. Šio tyrimo metu kèlème dvi prielaidas: 1) moteriška lytis, jaunesnis amžius ir žemesnis išsilavinimas bus susiję su didesne valgymo sutrikimų rizika; 2) išorinè mankštinimosi motyvacija, trumpesnis mankštinimosi stažas ir dažnesnis mankštinimasis bus susiję su didesne valgymo sutrikimų rizika.

\section{TYRIMO METODIKA}

Anketą sudarè demografinių klausimų blokas (respondentų buvo prašoma nurodyti savo amžių, lytị, išsilavinima) ir su mankštinimusi susijusių klausimų blokas (prašoma nurodyti savo mankštinimosi stažą (metais), mankštinimosi dažni ir kitus su mankštinimusi susijusius dalykus). Mankštinimosi stažas nustatytas atviru klausimu „Kiek metu (mènesių) Jūs mankštinatès sporto (sveikatingumo) centre (nebūtinai tik šiame)?", mankštinimosi dažnis - atviru klausimu „Kiek kartų per savaitę Jūs mankštinatès sveikatingumo centre?"

Valgymo sutrikimu rizika nustatyta taikant Požiūrio ì valgymą testą (Eating Attitude Test26, Garner, 1982). Jị sudaro 26 teiginių skalè su šešiais atsakymų variantais, išdèstytais nuo „labai dažnai“ (3) iki „niekada“ (0). Teiginiai pateikti tokie, kaip: „Ypač vengiu maisto, turinčio daug angliavandenių (duonos, ryžių, bulvių ir pan.)“, „Jaučiu, kad mityba valdo mano gyvenimą.“ Asmuo, surinkęs 20 balų ir daugiau, priskiriamas valgymo sutrikimų rizikos grupei ir turètų kreiptis i gydytojus bei pasitikrinti, ar neserga valgymo sutrikimais. Šios imties skalès vidinis nuoseklumas buvo geras $(\alpha=0,85)$.
Mankštinimosi motyvacija buvo nustatoma remiantis apsisprendimo teorijos pagrindu sukurtu klausimynu (angl. Motives for Physical Activity Measure-Revised, MPAM-R) (Frederick, Ryan, 1993). Klausimyną sudaro penkios motyvu skalès: fizinio pajègumo (angl. fitness) siekimo, išvaizdos gerinimo, fizinès kompetencijos gerinimo, socialiniu (bendravimo) motyvu ir malonumo siekimo. Teiginiu pavyzdžiai: malonumo skalès - „Mankštinuosi, nes sportuodama jaučiuosi laimingesnè(-is)“; fizinio pajègumo - „Mankštinuosi, nes noriu gerinti širdies ir kraujagyslių sistemos pajègumą"; išvaizdos skalès - „Mankštinuosi, nes noriu gerinti savo išvaizdą." Atsakymų variantai išdèstyti Likerto skalejje nuo „visiškai nesutinku“ (1) iki „visiškai sutinku“ (7). Tiriamujuc mankštinimosi motyvacija kiekvienoje skaleje vertinama pagal joje surenkamu balu skaičių. Šios imties malonumo, fizinès kompetencijos, bendravimo, išvaizdos ir fizinio pajègumo skaliu vidinis nuoseklumas buvo geras arba patenkinamas, atitinkamai: $\alpha=$ 0,$80 ; 0,62 ; 0,69 ; 0,80 ; 0,76$.

Tyrimo imtis ir organizavimas. Tyrimas buvo atliekamas 2008 metu pavasari komerciniuose Kauno sporto ir sveikatingumo centruose $(\mathrm{n}=11)$, taikant apklausos raštu metodą. Iš viso patogiuoju būdu buvo apklausti 256 sveikatingumo centruose besimankštinantys asmenys, iš jų -81 vyras (imties amžiaus vidurkis $30,8 \pm 8,9$ m.). Dèl apklausos iš anksto buvo susitarta su sporto ir sveikatingumo centrų vadovais. Išmokyta tyrèja kiekviename sporto ir sveikatingumo centre susitarta darbo dieną (po 17 valandos) apklausé po $20-25$ besimankštinančius asmenis, kurie mankštinosi ne trumpiau kaip pusę metu ir ne rečiau kaip du kartus per savaitę. Anketos buvo pildomos prieš pratybas arba po jų, užpildytos anketos iš karto surenkamos lankytojams išeinant iš sporto ir sveikatingumo klubo. Jauniausias tiriamasis 18-os, vyriausias - 58 metų amžiaus. Atsisakiusių dalyvauti tyrime nebuvo, tačiau 17 anketų sugadinta arba užpildyta nepilnai, todèl atmesta. Taigi analizuojami 239 tiriamujuc duomenys. Anketinè apklausa vykdyta remiantis anonimiškumo ir savanoriškumo principais.

Statistinè analizè. Duomenys buvo analizuojami naudojantis statistinès duomenu analizès programiniu paketu SPSS for Windows 13.0. Kokybinių požymių statistinis ryšys vertintas chi kvadrato kriterijumi. Lyginant dviejų nepriklausomų imčių neparametrinius duomenis taikytas Mann-Whitney $U$ testas. Ryšiams tarp kintamujų nustatyti buvo 
atliekama koreliacinè analizè (skaičiuojamas Spirmeno rho koeficientas). Norint išsiaiškinti, kaip nepriklausomi kintamieji susiję su priklausomu kintamuoju (valgymo sutrikimų rizika), buvo atliekama binarinè logistinè regresija (Enter modelis) ir skaičiuojami galimybių santykiai (GS). Rezultatai buvo laikomi statistiškai reikšmingais, jei vienetas neįeidavo i pasikliautinajji intervalą (PI). Visi rezultatai laikyti statistiškai reikšmingais, jeigu $\mathrm{p}<0,05$.

\section{REZULTATAI}

Atlikus Kolmogorovo-Smirnovo testą paaiškèjo, kad duomenys yra pasiskirstę nenormaliai, todèl analizuojant rezultatus buvo taikoma neparametrinių duomenų statistika. Lyginant vyrus ir moteris paaiškejjo, kad moterys buvo reikšmingai vyresnès (1 lent.), aukštesnio išsilavinimo negu vyrai - aukštaji išsilavinimą turejo $58,9 \%$ moteru ir $38,3 \%$ vyru $\left(\chi^{2}=9,09 ; \mathrm{df}=1 ; \mathrm{p}=0,003\right)$. Mankštinimosi stažas lyties grupèse reikšmingai nesiskyrè, tačiau moterys rečiau (mažiau kartu per savaitę) mankštinosi (1 lent.). Moterys kur kas dažniau mankštinosi dèl malonumo, fizinès išvaizdos gerinimo ir fizinio pajègumo motyvu negu vyrai.

Bendras šios imties valgymo sutrikimų rizikos balu vidurkis buvo 7,67 \pm 8 balo. I valgymo sutrikimų rizikos grupę (surinko 20 ir daugiau balų) pakliuvo $21(9,1 \%)$ tiriamasis, iš jų $-7(8,64 \%)$ vyrai ir $14(8,86 \%)$ moteru. Apskritai moteru valgymo sutrikimu rizika (bendras balas) buvo reikšmingai didesnè (1 lent.).

\begin{tabular}{|l|c|c|c|}
\hline \multicolumn{1}{|c|}{ Kintamieji } & Vyrai $(\mathbf{n}=\mathbf{8 1})$ & Moterys $(\mathbf{n}=\mathbf{1 5 8})$ & $\mathbf{p}$ \\
\hline Amžius, m. & $28,21(7,52)$ & $32,20(9,28)$ & 0,003 \\
\hline Mankštinimosi stažas, m. & $3,82(2,42)$ & $3,63(2,41)$ & 0,52 \\
\hline Mankštinimosi dažnis, k. / sav. & $2,96(0,84)$ & $2,70(0,73)$ & 0,003 \\
\hline Motyvacija: malonumas & $4,59(1,05)$ & $4,96(1,18)$ & 0,02 \\
\hline Motyvacija: kompetencija & $4,09(1,38)$ & $4,49(1,73)$ & 0,12 \\
\hline Motyvacija: išvaizda & $4,91(1,32)$ & $5,44(1,17)$ & 0,004 \\
\hline Motyvacija: fizinis pajėgumas & $5,19(1,23)$ & $5,99(0,99)$ & 0,001 \\
\hline Motyvacija: bendravimas & $3,54(1,63)$ & $3,74(1,71)$ & 0,51 \\
\hline Valgymo sutrikimų rizika & $6,29(7,33)$ & $8,36(8,25)$ & 0,02 \\
\hline
\end{tabular}

1 lentelè. Tyrimo kintamųjų vidurkiai (SD) ir skirtumo tarp lyčiu reikšmingumas

Pastaba. Kur nenurodyta, rodikliai pateikiami balais.

2 lentelè. Koreliacijos (Spirmeno rho) koeficientai tarp tyrimo kintamųjų

\begin{tabular}{|c|c|c|c|c|c|c|c|c|c|c|c|}
\hline Kintamieji & 1 & 2 & 3 & 4 & 5 & 6 & 7 & 8 & 9 & 10 & 11 \\
\hline Lytis & 1 & & & & & & & & & & \\
\hline Amžius & $0,19 * *$ & 1 & & & & & & & & & \\
\hline Išsilavinimas & $0,20 * *$ & $0,23 * *$ & 1 & & & & & & & & \\
\hline Motyvacija: idomumas & $0,16^{* *}$ & $-0,33$ & 0,02 & 1 & & & & & & & \\
\hline Motyvacija: kompetencija & 0,11 & $-0,11$ & $-0,02$ & $0,70^{* *}$ & 1 & & & & & & \\
\hline Motyvacija: išvaizda & $0,19 * *$ & $-0,13 *$ & 0,07 & $0,43 * *$ & $0,41 * *$ & 1 & & & & & \\
\hline Motyvacija: fizinis pajėgumas & $0,34 * *$ & 0,03 & 0,09 & $0,47 * *$ & $0,42 * *$ & $0,50 * *$ & 1 & & & & \\
\hline Motyvacija: bendravimas & 0,04 & 0,05 & $-0,06$ & $0,60 * *$ & $0,61 * *$ & $0,12 * *$ & $0,25 * *$ & 1 & & & \\
\hline Mankštinimosi stažas & $-0,04$ & $0,25 * *$ & $0,18^{* *}$ & 0,09 & $-0,03$ & 0,02 & 0,02 & 0,10 & 1 & & \\
\hline Mankštinimosi dažnis & $-0,19 * *$ & $-0,06$ & $-0,01$ & $0,13^{*}$ & 0,09 & 0,06 & 0,01 & 0,04 & $0,13^{*}$ & 1 & \\
\hline Valgymo sutrikimų rizika & 0,001 & $-0,12 *$ & $-0,03$ & 0,08 & 0,03 & $0,21 * *$ & 0,09 & 0,04 & $0,12 *$ & $0,14 *$ & 1 \\
\hline
\end{tabular}

Pastaba. * $-\mathrm{p}<0,05 ; * *-\mathrm{p}<0,01$. 


\begin{tabular}{|c|c|c|c|c|c|}
\hline \multirow{2}{*}{$\begin{array}{l}3 \text { lentelè. Valgymo sutrikimų rizikos ga- } \\
\text { limybių santykiai (GS) ir jų pasikliauti- } \\
\text { nieji intervalai, atsižvelgiant į analizuo- } \\
\text { jamus veiksnius }\end{array}$} & Kintamieji & B & GS & \multicolumn{2}{|c|}{ PI } \\
\hline & Lytis & 0,27 & 1,31 & 0,41 & 4,18 \\
\hline & Amžius & $-0,07$ & 0,94 & 0,86 & 1,01 \\
\hline & Išsilavinimas & $-0,53$ & 0,59 & 0,20 & 1,72 \\
\hline & Motyvacija: idomumas & $-0,07$ & 0,93 & 0,49 & 1,78 \\
\hline & Motyvacija: kompetencija & 0,004 & 0,98 & 0,74 & 1,37 \\
\hline & Motyvacija: išvaizda & 0,74 & 2,1 & 1,14 & 3,84 \\
\hline & Motyvacija: fizinis pajėgumas & $-0,27$ & 0,77 & 0,40 & 1,47 \\
\hline & Motyvacija: bendravimas & 0,02 & 1,02 & 0,71 & 1,47 \\
\hline & Mankštinimosi stažas & 0,33 & 1,39 & 0,98 & 1,96 \\
\hline & Mankštinimosi dažnis & 0,71 & 2,03 & 0,96 & 4,30 \\
\hline
\end{tabular}

Koreliacinè analizè atskleidè, kad vyresni tiriamieji rečiau mankštinasi vedami fizinès išvaizdos gerinimo motyvo, jų mankštinimosi stažas yra ilgesnis, o valgymo sutrikimų rizika mažesnè (2 lent.). Aukštesnis išsilavinimas reikšmingai nekoreliavo su mankštinimosi motyvacija ir valgymo sutrikimų rizika, tačiau aukštesnio išsilavinimo asmenų mankštinimosi stažas buvo ilgesnis.

Mankštinimasis dèl malonumo reikšmingai buvo susijęs su mankštinimosi dažniu. Pastebètas vidutinio stiprumo statistiškai reikšmingas ryšys tarp mankštinimosi dẻ išvaizdos ir fizinio pajègumo motyvų. Mankštinimasis dèl išvaizdos buvo vienintelis iš motyvų, reikšmingai susijęs su didesne valgymo sutrikimų rizika. Didesnis mankštinimosi stažas ir mankštinimosi dažnis taip pat buvo susiję su didesne valgymo sutrikimų rizika.

Lyginant visų analizuojamų veiksnių galimybių santykius ir prognozuojant analizuojamos imties valgymo sutrikimų riziką nustatyta, kad mankštinimasis dèl išvaizdos du kartus didina valgymo sutrikimų rizikos galimybę $(\mathrm{p}<0,05)$. Mankštinimasis dèl fizinio pajègumo, nors ir statistiškai nereikšmingai, šią galimybę mažina. Aptikta tendencija, kad valgymo sutrikimų rizikos galimybę didina moteriška lytis, didesnis mankštinimosi stažas ir dažnumas. Modelio $\chi^{2}=21,5$, $\mathrm{df}=1, \mathrm{p}=0,02 ;$ Nagerkelke $\mathrm{R}^{2}=0,21$.

\section{REZULTATUQ APTARIMAS}

Šiuo tyrimu kèlėme prielaidą, kad moteriška lytis, jaunesnis amžius ir mažesnis išsilavinimas bus susiję su didesne valgymo sutrikimų rizika. Ši prielaida pasitvirtino tik iš dalies, kadangi nè vienas iš tirtų kintamujų statistiškai reikšmingai neprognozavo valgymo sutrikimu rizikos galimybès galutiniame logistinès regresijos modelyje, nors aptiktos tendencijos, kurių tikejjomès. Mūsų duomenys sutampa ir su kitų autorių gautaisiais valgymo sutrikimų rizika būdingesnè moterims nei vyrams (Austin et al., 2008). Naujesnių tyrimu su sveikatingumo centruose besimankštinančiais asmenimis aptikti nepavyko. Jaunesnis amžius nebuvo susijęs su dažnesne valgymo sutrikimų rizika, ir tai patvirtina kitu autorių keliamą prielaidą, kad valgymo sutrikimų rizika gali būti panaši tarp vyresnių ir jaunesnių moteru (Peat et al., 2008). Deja, beveik nieko negalima pasakyti apie besimankštinančius vyrus, nes tokių duomenų aptikti nepavyko.

Nustatyta tendencija, kad aukštesnis išsilavinimas, kaip ir tikètasi, susijęs su mažesne valgymo sutrikimu galimybe. Tai gali būti aiškinama taip: aukštesnio išsilavinimo asmenys turi daugiau ir tikslesnių žiniu apie kūno masès kontrolę ir galbūt rečiau siekia mažinti kūno masę, juolab kad jų kūno masė taip pat yra mažesnè (Klumbiene et al., 2004). Be to, žemesnio išsilavinimo moterys 
prasčiau priima per žiniasklaidą perduodamą informaciją apie sveiką gyvenseną (Iversen, Kraft, 2006). Gauti duomenys remia M. C. E. Gard ir C. P. Freeman (1998) idejją, kad valgymo sutrikimu rizika gali būti dažnesnè tarp žemesnio išsilavinimo asmenu̧, nors juos reikètų patikrinti ir kitomis studijomis.

Studentiškų imčių tyrimai atskleidžia, kad valgymo sutrikimų rizika būdinga maždaug $8,4-15 \%$ studenčių ir 4-8\% studentu (O`Dea, Abraham, 2002; Austin et al., 2008) ir panaši dalis studentiško amžiaus vyrų ir moterų laikosi dietos svorio kontrolès tikslais (C. N. Markey, P. M. Markey, 2005). Taigi mūsų gauti duomenys iš esmès yra panašūs, nors juos vertetų palyginti su analogišku imčių tyrimo rezultatais.

Antroji prielaida teigè, kad išorinè mankštinimosi motyvacija (mankštinimasis dèl išvaizdos) ir trumpesnis mankštinimosi stažas bus susiję su didesne valgymo sutrikimų rizika. Tyrimas visiškai patvirtino pirmą prielaidos dalị: mankštinimasis dèl išvaizdos motyvo reikšmingai buvo susijęs su didesne valgymo sutrikimų rizika. Mūsų tyrimo duomenys sutapo su kitų mokslininkų gautaisiais - valgymo sutrikimais sergančios moterys dažniau mankštinasi dèl fizinès išvaizdos gerinimo motyvų (Mond, Calogero, 2009). Gauti duomenys atitinka apsisprendimo motyvacijos teorines prielaidas ir leidžia manyti, kad apsisprendimo teorija gali būti taikoma ir tolesniu kūno vaizdo ir valgymo sutrikimų rizikos sąsajų tyrimų metu.

Priešingai negu tikètasi, buvo aptikta tokia tendencija - ilgesnis mankštinimosi stažas susijęs su didesne valgymo sutrikimų rizika. Didesnis mankštinimosi stažas būdingas vyresniems ir aukštesnio išsilavinimo asmenims, nors išsilavinimas nebuvo susijęs su didesne valgymo sutrikimu rizika, o vyresnis amžius buvo susijęs su mažesne valgymo patologija. Todẻl mankštinimosi stažas gali būti laikomas nepriklausomu veiksniu, prisidedančiu prie valgymo sutrikimų. Analogišku tyrimu aptikti nepavyko, todèl šis rezultatas turi būti tikrinamas tolesnèse studijose.

Kaip ir tikètasi, mankštinimosi dažnis buvo susijęs su didesne valgymo sutrikimų rizika. Tai atitinka ir kitu autorių duomenis, kurie teigia, kad valgymo sutrikimais sergantys asmenys dažnai perdozuoja fizini krūvị arba valgymo sutrikimus, juos lydi priklausomybė nuo mankštinimosi (angl. exercise dependence). Tyrimai rodo, kad net $42 \%$ sveikatingumo centrų lankytojų atitinka priklausomybės nuo mankštinimosi diagnostinius kriterijus
(Lejoyeux et al., 2008). Skiriama pirmine ir antrinè priklausomybè nuo mankštinimosi. Antrinei priklausomybei būdinga tai, kad paprastai asmeniui diagnozuojami valgymo sutrikimai, o perdozuotą mankštinimąsi toks asmuo naudoja savo kūno masei mažinti arba persivalgymo pasekmèms likviduoti (Bamber et al., 2000).

Nepaisant to, kad daugelis tyrimų rodo sveikatingumo centrų lankymo ir sveikesnės gyvensenos sąsajas, verta atkreipti dėmesi i besimankštinančiu asmenu su svorio kontrole susijusi elgesi, nes beveik dešimtadalis tirtų sportuotojų turi valgymo patologijos požymių ir galbūt perdozuotai mankštinasi. Deja, yra tyrimų, kurie atskleidžia, kad mankštinimasis sveikatingumo centruose, o ne kitur, yra labiau susijęs su dažnesniais valgymo sutrikimais (Augestad et al., 1999).

Šis tyrimas išsklaido mitą, kad kūno svorio kontrolès problemos iš esmès būdingos tik moterims ir atskleidžia vyrų kūno vaizdo problematiškumą - nors daugelis vyrų siekia kuo daugiau priaugti kūno masès, dalis jų bando mažinti riebalini audini manipuliuodami maistu. Iš esmès tyrimas svarbus tuo, kad jis padeda pagristi sveikatos ugdymo programu reikalingumą. Šios programos nebūtinai reikalingos tik jauno amžiaus besimankštinančių moterų grupèms, valgymo sutrikimų prevencija būtina visiems besimankštinantiems, nepaisant lyties ir amžiaus.

Pagrindini tyrimo trūkumą sudaro nedidelè tiriamuju, ypač vyrų, imtis, kuri neleidžia apibendrinti visos besimankštinančiujuc populiacijos rezultatų. Tam reikalingi didesnių besimankštinančiu asmenų imčių tolesni tyrimai.

Kitas tyrimo trūkumas sietinas su klausimyno (angl. Motives for Physical Activity Measure-Revised, MPAM-R) (Frederick, Ryan, 1993) ribotumais, neleidusiais plačiau pasiremti apsisprendimo motyvacijos teorija (klausimynas leidžia nustatyti tik penkis motyvus, o jų iš esmès gali būti kur kas daugiau). Be to, patys motyvai nerodo autonomiškos arba kontroliuojamosios reguliacijos lygmens. Pavyzdžiui, motyvacija mankštintis gali atskleisti asmens siekimą mankštintis dèl išvaizdos, nes jis asmeniškai labai vertina išvaizdos svarbą ir jam labai malonu siekti geresnès išvaizdos per mankštinimąsi, arba priešingai, asmuo gali jaustis verčiamas gerinti išvaizdą norèdamas patenkinti kitų lūkesčius, o ne savo norus. Tada išvaizdos gerinimas per fizini aktyvuma jam nesuteikia jokio malonumo (kontroliuojamoji motyvacijos reguliacija). Todèl tolesnių tyrimų metu vertètu taikyti ir atskirus motyvus, nustatančius instrumentus, ir 
tuos, kuriais nustatomi reguliaciniai motyvacijos mechanizmai.

Tolesni tyrimai galètų būti nukreipti didesnès imties valgymo sutrikimų rizikos paplitimo ir ỉvairių su mankštinimusi susijusių veiksnių ryšiams tirti, lyginant sveikatingumo centruose ir kitur besimankštinančių asmenų valgymo sutrikimu rizikos sklaidą. Tai padètu atsakyti i klausimą, ar iš tikrujų sveikatingumo centru aplinkoje yra veiksnių, kurie skatina valgymo sutrikimų plètotę. Stebejjimo ir eksperimentiniai tyrimai padètu atsakyti į klausimą apie besimankštinančių asmenu motyvacijos ir kūno vaizdo ryšių priežastingumą.

\section{IŠVADOS}

Valgymo sutrikimų rizika yra paplitęs reiškinys tarp besimankštinančių asmenų. Moteriška lytis, amžius ir didesnis išsilavinimas nèra reikšmingai susiję su sveikatingumo centruose besimankštinančių asmenų valgymo sutrikimų rizika. Mankštinimasis dèl išvaizdos gerinimo motyvo yra svarbiausias valgymo sutrikimus prognozuojantis veiksnys $(p<0,05)$. Tyrimas pagrindžia kūno vaizdo prevencinių programų sveikatingumo centruose reikalingumą ir atskleidžia šių programų būtinybę vyrams.

\section{LITERATŪRA}

Abraham, S. F., Pettigrew, B., Boyd, C., Russell, J. (2006). Predictors of functional and exercise amenorrhoea among eating and exercise disordered patients. Human Reproduction, 21 (1), 257-261.

de Araujo, D. S., de Araujo, C. G. (2003). Self-perception and dissatisfaction with weight does not depend on the frequency of physical activity. Arquivos Brasileiros de Cardiologia, 80 (3), 235-249.

Augestad, L. B., Saether, B., Gotestam, K. G. (1999). The relationship between eating disorders and personality in physically active women. Scandinavian Journal of Sports Medicine, 9, 304-312.

Austin, S., Ziyadeh, N., Forman, S. et al. (2008). Screening high school students for eating disorders: Results of a national initiative. Preventing Chronic Disease, 5 (4), A $114-114$.

Baghurst, T., Lirgg, C. (2009). Characteristics of muscle dysmorphia in male football, weight training, and competitive natural and non-natural bodybuilding samples. Body Image, 6 (3), 221-227.

Bamber, D., Cockerill, I., M., Rodgers, S., Carrol, D. (2000). "It's exercise or nothing": A qualitative analysis of exercise dependence. British Journal of Sports Medicine, 34, 423-430.

Chu, H., Bushman, B., Woodard, R. (2008). Social physique anxiety, obligation to exercise, and exercise choices among college students. Journal of American College Health: $J$ Of ACH, 57 (1), 7-4.

Depick, E., Williams, L. (2004). Weight training and body satisfaction of body - image disturbed college women. Journal of Applied Sport Psychology, 16 (3), 287-299.

Frederick, C. M., Ryan, R. M. (1993). Differences in motivation for sport and exercise and their relationships with participation and mental health. Journal of Sport Behaviour, 6, 125-145.

Gard, M. C. E., Freeman, C. P. (1998). The dismantling of a myth: A review of eating disorders and socioeconomic status. International Journal of Eating Disorders, 20 (1), $1-12$.

Garner, D. M., Olmsted, M. P., Bohr, Y., Garfinkel, P. E. (1982). The Eating Attitudes Test: Psychometric features and clinical correlates. Psychological Medicine, 12, $871-878$.
Herzog, D. B., Greenwood, D. N., Dorer, D. J. et al. (2000). Mortality in eating disorders: A descriptive study. International Journal of Eating Disorders, 28, 20-26.

Iversen, A. C., Kraft, P. (2006). Does socio-economic status and health consciousness influence how women respond to health related messages in media? Health Education Research, 21 (5), 601-610.

Keel, P. K., Baxter, M. G., Healtherton, T. F., Joiner, T. E. J. (2007). A 20-year longitudinal study of body weight, dieting, and eating disorders symptoms. Journal of Abnormal Psychology, 116 (2), 422-432.

Kjelsas, E., Augestad, L. B. (2004). Gender, eating behavior, and personality characteristics in physically active students. Scandinavian Journal of Science and Sports, 14, 258-268.

Klumbiene, J., Petkevičienè, J., Helasoja, V., Prattala, R., Kasmel, A. (2004). Sociodemographic and health behaviour factors associated with obesity in adults populations in Estonia, Finland and Lithuania. European Journal of Public Health, 14 (4), 390-400.

Krauth, C., Buser, K., Vogel, H. (2002). How high are the costs of eating disorders - anorexia nervosa and bulimia nervosa - for German society? European Journal of Health Economics, 3, 244-250.

Lejoyeux, M., Avril, M., Richoux, C., Embouazza, H., Nivoli, F. (2008). Prevalence of exercise dependence and other behavioural addictions among clients of a Parisian fitness room. Comprehensive Psychiatry, 49 (4), $353-358$.

Markey, C. N., Markey, P. M. (2005). Relations between body image and dieting behaviors: An examination of gender differences. Sex Roles, 53 (7-8), 519-530.

Mond, J., Calogero, R. (2009). Excessive exercise in eating disorder patients and in healthy women. The Australian and New Zealand Journal of Psychiatry, 43 (3), $227-234$.

Mond, J., Hay, P., Rodgers, B., Owen, C. (2006). An update on the definition of excessive exercise in eating disorders research. The International Journal of Eating Disorders, 39 (2), 147-153.

O'Dea, J. A., Abraham, S. (2002). Eating and exercise disorders in young college men. Journal of American College Health, 50 (6), 273-278. 
Peat, C., Peyerl, N., Muehlenkamp, J. (2008). Body image and eating disorders in older adults: A review. The Journal of General Psychology, 135 (4), 343-358.

Reinking, M. F., Alexander, L. E. (2005). Prevalence of disordered-eating behaviors in undergraduate female collegiate athletes and nonathletes. Journal of Athletic Training, 40 (1), 47-51.

Ryan, R. M., Frederick, C. M., Lepes, D., Rubio, N., Sheldon, K. M. (1997). Intrinsic motivation and exercise adherence. International Journal of Sport Psychology, 28, $335-354$.

Seigel, K., Hetta, J. (2001). Exercise and eating disorder symptoms among young females. Eating and Weight Disorders, 6 (1), 32-39.
Šivert, Š. Š., Sinanovič, O. (2008). Body dissatisfaction is age a factor? Facta Universitatis, 7 (1), 55-61.

Teixeira, P. J., Going, C. B., Houtkooper, L. B. et al. (2006). Exercise motivation, eating, and body image variables as predictors of weight control. Medicine and Science in Sport and Exercise, 38, 179-188.

Walker, D., Anderson, D., Hildebrandt, T. (2009). Body checking behaviors in men. Body Image, 6 (3), 164170.

Zabinski, M. F., Calfas, K. J., Gehrman, C. A., Wilfley, D. E., Sallis, J. F. (2001). Effects of physical activity intervention on body image in university seniors: Project GRAD. Annals of Behavioral Medicine, 23 (4), $247-252$.

\title{
THE RELATIONSHIP BETWEEN DEMOGRAPHIC FACTORS, EXERCISE MOTIVES AND DISORDERED EATING IN EXERCISING SAMPLE
}

\author{
Rasa Jankauskienė, Rasa Mickūnienè \\ Lithuanian Academy of Physical Education, Kaunas, Lithuania
}

\begin{abstract}
A plethora of research shows that eating disorders are more common among professional athletes, especially aesthetic sports compared to general populations. The research showed that fitness centre exercisers more frequently demonstrated symptoms of disordered eating compared to exercisers of other sports settings. The relationship between eating disorders and exercise - related attitudes and behaviour has been well documented in the young populations, yet less is known how demographic and exercise - related factors are related in populations of adult exercisers at fitness centres.

The aim of this study was to assess how demographic (gender, age and education) and exercise related (motivation, experience, frequency) factors were related to the risk of eating disorders in fitness centres exercisers.

Method. The study was carried out in spring of 2008 in several Kaunas health and fitness centres. The data were collected using the method of anonymous questioning. The sample consisted of 239 respondents, 81 of them were men (mean age $30.8 \pm 8.9$ years).

The instrument. The demographic data were collected. The risk of eating disorders was assessed using Eating Attitude Test - 26; EAT -26, Garner, 1982. Exercise motivation was assessed by Motives for Physical Activity Measure-Revised; MPAM-R (Frederick, Ryan, 1993).

Results. The mean score for EAT-26 in the sample was $7.67 \pm 8.21(9.1 \%)$ of the sample demonstrated the symptoms of eating disorders (EAT $\geq 20), 7(8.6 \%)$ of them were men and $14(8.9 \%)$ women. Logistic regression analysis showed that the strongest significant predictor of disordered eating was exercising due to appearance improvement.

Conclusions The risk of eating disorders was typical of persons exercising in fitness settings. The study showed the necessity to enhance the internal exercise motivation in exercising samples and the need for the body image prevention in fitness settings not only in the young female samples but for the exercising men as well.
\end{abstract}

Keywords: eating disorders, physical activity, exercise motives.

Gauta 2009 m. rugsèjo 15 d.

Received on September 15, 2009

Priimta 2010 m. gegužès $31 \mathrm{~d}$.

Accepted on May 31, 2010
Rasa Jankauskienè,

Lietuvos kūno kultūros akademija

(Lithuanian Academy of Physical Education)

Sporto g. 6, LT-44221 Kaunas

Lietuva (Lithuania)

Tel +370 37302638

E-mail r.jankauskiene@1kka.lt 